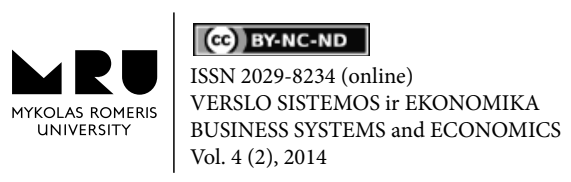

\title{
CURRENT ACCOUNT DEFICIT AND GLOBAL COMPETITIVENESS IN TURKEY
}

\author{
Nuray TERZI \\ Marmara University, Department of Economics \\ 34722 Goztepe, Istanbul, Turkey \\ E-mail: nurayterzi@marmara.edu.tr \\ doi:10.13165/VSE-14-4-2-02
}

\begin{abstract}
Current account deficit has been at the core of policy discussions in recent years in Turkey. The current account deficit in Turkey has exceeded the risky level. Policy makers worry that the enlarging current account deficit will further jeopardize Turkey's economic future, making it more vulnerable to external economic fluctuation. The greatest portion of the current account deficit in Turkey results from increased trade deficit, and the main parts of imports in Turkey focus on some specific countries. A comparison between Turkey and its trade partners in terms of global competitiveness will provide a deep insight to reduce the deficit as well as the current account deficit. For this reason, this study aims to compare the level of global competitiveness of Turkey and its main trade partners.
\end{abstract}

Keywords: current account deficit, trade deficit, global competitiveness. JEL classification: F32, F60.

\section{Introduction}

Current account deficit has been at the core of policy discussions in recent years in Turkey. During the post crisis period, rapid credit growth and excessive appreciation pressures driven by capital flood episodes and the consequent deterioration in the external accounts have increased the fragility of the economy against global liquidity shocks. The current account deficit in Turkey exceeded the 7 percent of GDP in 2013. Since 2007, the deficit has averaged 6.2\% against 2.6\% for the other four 'Fragile Five' economies - South Africa, India, Indonesia and Brazil. The latest rise in the current account deficit has been attributed mainly to an increase in foreign trade deficit, and Turkey's foreign trade deficit in 2013 rose 18.7 percent to reach 99.8 billion dollars.

Policy makers worry that the enlarging the current account deficit will further jeopardize Turkey's economic future, making it more vulnerable to external economic fluctuation. As a result, the most significant economic issue in Turkey today has become the lowering of the current account deficit. The lowering of the current account deficit does not depend only on national conditions, but also on the global conditions. 
For this reason, the main research questions of this study are who the main trade partners of Turkey are and what global competitive differences between Turkey and the main trade partners exist. Therefore, this paper aims to compare the level of global competitiveness of Turkey and its main trade partners. To achieve this aim, the study will focus on literature reviews and use some important economic indicators as well as global competitiveness indicators as a research method.

The present paper is organized as follows. First of all, this study reviews some developments about the current account deficit in Turkey by giving reasons for the current account deficits in Turkey. Secondly, it explains the main trade partners of Turkey. Thirdly, it provides a comparison between Turkey and its main trade partners in terms of global competitiveness, and finally it draws a conclusion.

\section{Developments about the Current Account Deficit in Turkey}

The current account of the balance of payments refers to the monetary value of international flows associated with transactions in goods and services, investment income and unilateral transfers (Carbaugh, 2006, p. 321). In other words, current account deficit for a country means that the country is spending more than its income is (Appleyard et al., 2010, p. 464). Current account balance can be characterized into three approaches: trade balance, saving-investment balance and net capital inflow. Firstly, the current account balance is portrayed as the difference between nation's exports and it imports. From this perspective, the determinants of the current account balance are roughly the same as the determinants of the trade balance: exchange rates, prices and incomes domestically and abroad. According to the second perspective, the current account is derived from the difference between nation's saving and its investment. Finally, the current account deficit is equivalent to the net inflow of capital from abroad because any excess of national spending over income must be financed by foreigners (Ferguson, 2005, p. 2).

During the post-crisis period, rapid credit growth and excessive appreciation pressures driven by capital flood episodes and the consequent deterioration in the external accounts have increased the fragility of the economy against global liquidity shocks. In this process, effective macroeconomic and structural policies helped the Turkish economy rebound vigorously following the global crisis: growth averaged close to $9 \%$ in 2010-2011. However, the current account deficit widened to around 10\% of GDP and consumer price inflation rose to over $10 \%$. Although the economic slowdown since the mid-2011 is helping to reduce these external and domestic imbalances, energy prices have continued to rise, affecting the current account deficit in Turkey.

Turkey's economy accelerated in 2013, but the medium-term prospects for growth are to remain below potential. With the recovery in domestic demand, concerns over external imbalances and inflation have also made a comeback in the context of less accommodating global financial conditions (WB, 2014, p. 1).

Figure 1 shows the current account deficit, non-energy deficit and energy deficit in Turkey between 2000 and 2013. As it can be seen from the figure, the current account deficit has an increasing trend, excluding 2009 and 2012. The greatest portion of the current account deficit in Turkey results from increased energy deficit. Non-energy deficit is quite low. Therefore, energy dependency is one of the most important reasons for the current account deficit. 
Figure 1: Current Account Deficit: Energy and Non-energy (as \% of GDP)

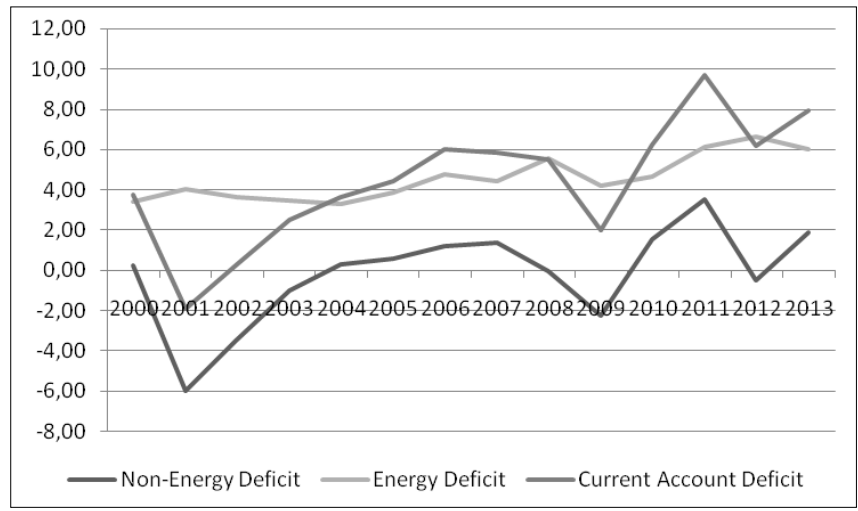

Source: TDM (2014)

The second reason of the current account deficit is increased trade deficit in Turkey. Figure 2 shows trade deficit in Turkey between 2000 and 2013. As a result of both strong domestic demand and competitiveness losses, it leads to rise in import penetration in consumer, intermediate and capital goods markets (OECD, 2012, p. 6). At the same time, exports increased only moderately as a result of weakness in foreign markets, due to the debt crisis in the euro area and political turmoil in MENA (Middle East and North Africa) region (CBRT, 2013, p. 7), but also losses in Turkish exporters' market shares during crisis.

Figure 2: Trade Deficit in Turkey (as \% of GDP)

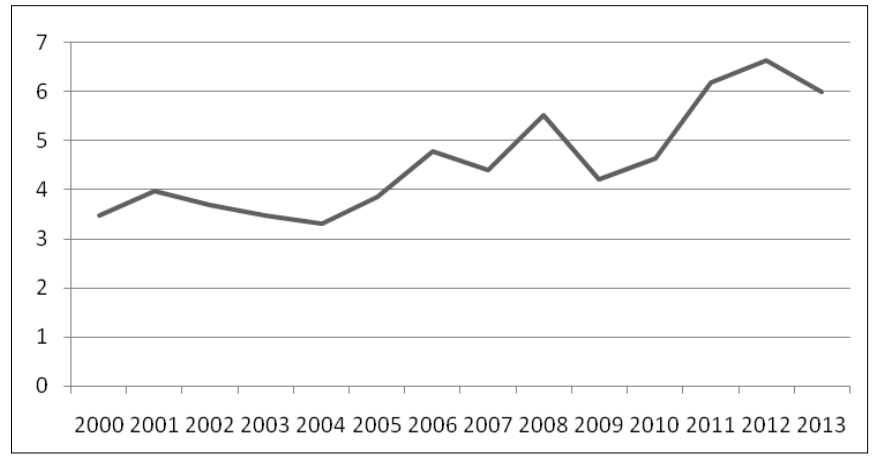

Source: TSI (2014)

Especially, the most important reason for increased imports is industrially-processed raw materials. Which industries need to import these materials? The industries which play the most important roles in Turkey's foreign trade deficit are mainly chemistry industry, metal industry, machine manufacturing industry and automotive industry. The share of chemical industry is $14.8 \%$ and the share of metal industry is $10.3 \%$ in total imports. Machinery is about $8.5 \%$ and automotive industry is about $5 \%$. The share of these four industries in total imports is almost $40 \%$ (Table 1). 
Table 1: Imports by ISIC, Rev. 3 Classification, 2014

\begin{tabular}{|r|c|}
\hline & $\begin{array}{c}\mathbf{2 0 1 4}^{\star} \\
\text { (Share in Total) }\end{array}$ \\
\hline Agriculture and Forestry & $\mathbf{3 , 3}$ \\
\hline Mining and Quarrying & $\mathbf{1 7 , 7}$ \\
\hline Manufacturing Chemicals and Chemical Products & $\mathbf{7 4 , 4}$ \\
\hline Manufacture of Basic Metals & 14,8 \\
\hline Manufacture of Machinery and Equipment & 10,3 \\
\hline Motor Vehicles and Trailers & 8,5 \\
\hline Orthers & 5,0 \\
\hline $\begin{array}{r}\text { Others (fishing, electricity, gas and water supply, wholesale and } \\
\text { retail trade, business activities, social and personal activities) }\end{array}$ & 35,8 \\
\hline
\end{tabular}

Source: TSI (2014)

*January

The third reason for the current account deficit is an increased saving-investment gap in Turkey. The widening trade deficit is the opening-up of a domestic saving-investment gap from the beginning of the 2000s (Figure 3). This gap reflects both a permanent decline in private saving and a surge in private investment. In contrast to private saving, public deficits turned into surpluses in the 2000s on the back of steady fiscal consolidation. However, this only partly offset the drop in private saving. Public investment remained relatively stable throughout the entire period.

Figure 3: Saving-Investment Balance (as \% of GDP), 1998-2012

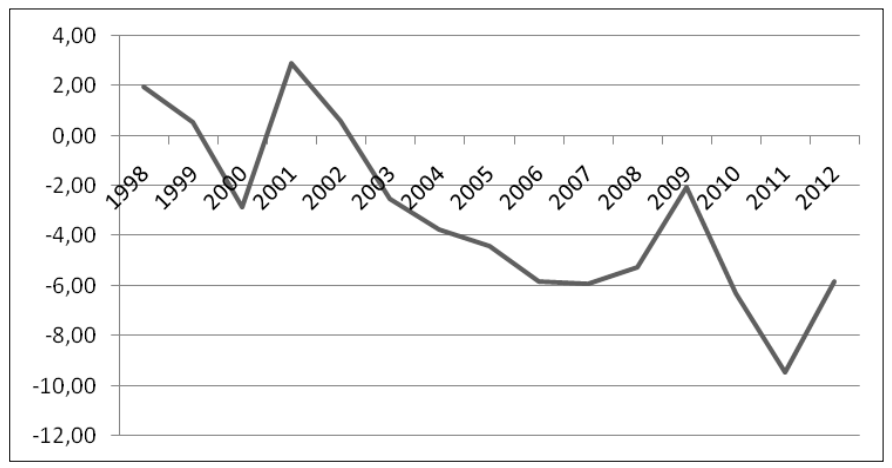

Source: TDM (2014)

In a country with a goal of sustainable growth, it is vitally important to increase domestic savings. In Turkey, the domestic savings ratio has fallen significantly below the average of developing countries since 2003. While the ratio of domestic savings to GDP is approximately 45 percent in East Asian developing countries, it is around 15 percent in Turkey (YASED, 2011, p. 5).

As the current account deficit essentially results from a foreign trade deficit in Turkey, the appreciation in the real exchange rate could help increase the foreign trade deficit. Therefore, the fourth reason for the current account deficit is appreciation in real exchange 
rate. As it follows from Figure 4, the Turkish Lira remained over-valued from a long-term growth perspective, excluding 2006-07, 2011-07 and 2014-01. The over valued Turkish Lira makes the country become less competitive in global markets.

Figure 4: Real Effective Exchange Rate $(2003=100)$

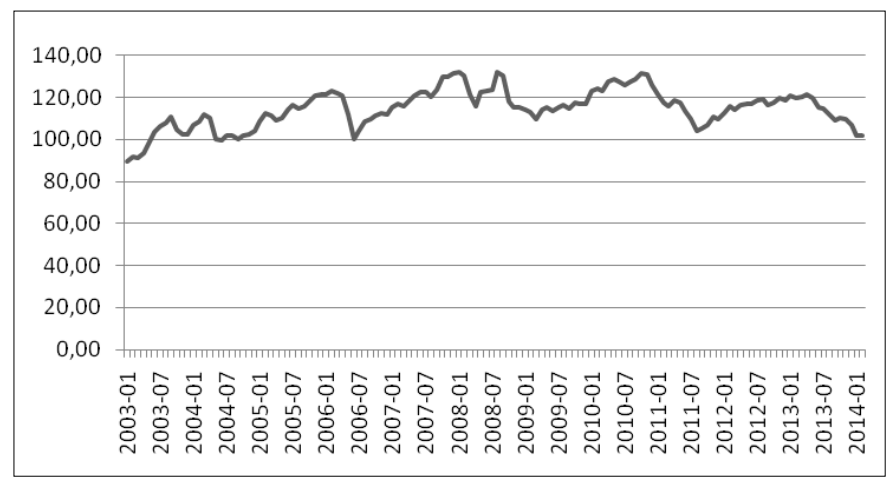

Source: CBRT (2014)

The current account deficit also reflects the Turkey's poor competitiveness globally. The deterioration in export performance arises from a steady deterioration of competitiveness. Competitiveness also takes place in the center of other reasons. According to Global Competitiveness Report, Turkey showed a moderate improvement in competitive performance between 2004 and 2013. The competitiveness of Turkey rose to 44th place out of 148 countries in 2013 (Table 2). However, Turkey is still behind the main trade partners in the European Union. Moreover, if the euro area crisis was to intensify, Turkey would be adversely affected through foreign trade.

Table 2: Global Competitiveness Index

\begin{tabular}{|l|c|c|}
\hline \multicolumn{1}{|c|}{ Year } & Number of Countries & Turkey's Rank \\
\hline 2004 & 104 & 66 \\
\hline 2005 & 117 & 66 \\
\hline 2006 & 125 & 59 \\
\hline 2007 & 131 & 54 \\
\hline 2008 & 134 & 63 \\
\hline 2009 & 133 & 61 \\
\hline 2010 & 139 & 61 \\
\hline 2011 & 142 & 59 \\
\hline 2012 & 144 & 43 \\
\hline 2013 & 148 & 44 \\
\hline
\end{tabular}

Source: Global Competitiveness Reports, World Economic Forum (2014)

As a result, the reasons of the current account deficit focus on the increased energy deficit, imports of raw materials, lower savings, over valued Turkish liras and deteriora- 
tion of global competitiveness. A country's competitiveness is widely accepted as the key driver for sustaining prosperity and raising the current account balance. Enhancing competitiveness is a long-term process that requires improvement across many areas as well as long-lasting commitments from relevant stakeholders to mobilize resources, time and effort. In the following section, first of all, the main trade partners of Turkey will be given, and then the level of global competitiveness between Turkey and its main trade partner will be compared.

\section{Main Trade Partners of Turkey}

In Turkey, permanent increased imports have been the main economic problem for many years. The sources of the imports in Turkey consist of the demand on specific goods which come from certain countries. Table 3 shows the top 5 countries in imports in Turkey in 2013. According to this table, Russia comes first, China ranks second. Others are Germany, Italy and the USA, respectively. The share of these five countries in total import is almost $40 \%$. The rest of them is $60 \%$, but the share of them is less then $5 \%$.

Table 3: Top 5 Countries in Imports in Turkey, 2013

\begin{tabular}{|c|l|c|c|}
\hline Rank & \multicolumn{1}{|c|}{ Countries } & $\mathbf{0 0 0} \mathbf{\$}$ & Share in Total (\%) \\
\hline 1 & Russia & 25.064 .214 & 10 \\
\hline 2 & China & 24.685 .885 & 9,8 \\
\hline 3 & Germany & 24.181 .597 & 9,6 \\
\hline 4 & Italy & 12.884 .844 & 5,1 \\
\hline 5 & USA & 12.596 .170 & 5,0 \\
\hline & Others & 152.237 .932 & 60,5 \\
\hline Total & & 251.650 .642 & 100 \\
\hline
\end{tabular}

Source: TSI (2014)

Russia was Turkey's first largest import partner in 2013. Turkey's imports from Russia are displaying a tendency towards steady and absolute growth. In 2013, Turkey's import from Russia became 25 billion USD. The top import categories were natural gas, crude oil and petroleum products (TME, 2013, p. 1).

Turkey's second largest import partner in 2013 was China. Turkey's imports from China were realized as 24.6 billion USD in 2013. The top import categories were telecom and sound recorders, electrical machines and their apparatus, office machinery and dataprocessing equipment, general industrial machinery and equipment, textile yarn, fabrics; made-up articles.

Another main trade partner of Turkey was Germany. Turkey's imports from Germany reached 24.1 billion USD, and Germany was Turkey's third largest supplier of goods in 2013. The top import categories were road vehicles, machinery specialized for particular industries, general industrial machinery and equipment, machine parts, electrical machinery, apparatus, appliances and electrical parts thereof, energy-generating machinery and equipment.

Currently, Italy is also one ofthe most important Turkey's trading partners among the EU member states. It occupied the fourth position in imports according to the trade num- 
bers of 2013. Turkey's import from Italy reached 12.8 billion USD. The top import categories were general petroleum, petroleum products and related materials; industrial machinery, equipment and machine parts; machinery specialized for particular industries; road vehicles; iron and steel.

The USA is currently Turkey's other largest trading partner in the world, and imports with the USA are about 12.6 billion USD. The USA was Turkey's fifth largest supplier of goods imports in 2013. The top 5 imports were the metalliferous ores and metal scrap; other transport equipment; petroleum, petroleum products and related materials; coal, coke and briquettes; textile fibres.

As a result, these top 5 countries have become the most importing trading partners of Turkey. The biggest part of the current account deficit comes from the trade deficit of Turkey. Therefore, it is crucial to decrease the imports of Turkey. To compare Turkey and its main trade partners in terms of global competitiveness will help to understand the deficiencies of economy. In the following part, the global competitiveness differences of Turkey against China, Russia, Germany, the US and Italy will be presented.

\section{Comparison between Turkey and Its Trade Partners in Terms of Global Competitiveness}

Globalization and trade liberalization coupled with rapid advances in information and communications technology have resulted in an unprecedented intensification of market competition worldwide. The global competitiveness is an important determinant for the well-being of states in an international trade environment. According to Global Economic Forum, global competitiveness is "the ability of a country to achieve sustained high rates of growth in gross domestic product per capita".

Therefore, only nations with high levels of productivity become domestically and globally competitive and have the capacity to exploit existing market opportunities to sustain and expand employment and real income growth in the long term. The imperatives for global competitiveness involve addressing the following issues: macroeconomic policies; government practices and regulations; the cost of doing business; education and skills upgrading; R\&D and innovation; sustainable environmental management; conformity with international standards; total factor productivity (Abdullah, 2014, p. 1).

According to Global Competitiveness Index, Turkey is ranked in the 44th place among 148 countries (Table 4). Turkey is behind its main trade partners, Germany, the USA and China, while Turkey comes before Italy and Russia in ranking. Italy and Russia are ahead in the rankings, although they are the main import partners of Turkey. This situation may seem like a contradiction. However, global competitiveness is only a weight average of many different components, each measuring a different aspect of competitiveness. For a detailed analysis, sub-components of global competitiveness have to be considered. Thus, the competitiveness differences between Turkey and its main trade partners will be shown. 
Table 4: Global Competitiveness Index, 2013-2014 Rankings

\begin{tabular}{|l|c|}
\hline & Rank (out of 148) \\
\hline Germany & 4 \\
\hline USA & 5 \\
\hline China & 29 \\
\hline Turkey & $\mathbf{4 4}$ \\
\hline Italy & 49 \\
\hline Russia & 64 \\
\hline
\end{tabular}

Source: World Economic Forum, Global Competitiveness Report 2013-2014

The components of global competitiveness are grouped into 12 pillars of competitiveness. These are institutions, infrastructure, macroeconomic environment, health and primary education, higher education and training, goods market efficiency, labor market efficiency, financial market development, technological readiness, market size, business sophistication and innovation. The first six pillars are shown in Table 5 and others are presented in Table 6.

The first pillar is the institutions. The institutional environment is determined by the legal and administrative framework within which individuals, firms and governments interact to generate wealth. The importance of a fair institutional environment has become all the more apparent during the recent economic and financial crisis and is especially crucial for solidifying the fragile recovery further, given the increasing role played by the state at the international level and for the economies of many countries (WEF, 2013, p. 4). In terms of institutions, Turkey's economy is followed by Germany, the USA and China, by being ranked 56th. Italy and Russia are behind Turkey and their ranks are 102 and 121, respectively. Germany has the best situation among the Turkey's main trade partners. Turkey's economy needs to improve the institutionals level to be more competitive.

Infrastructure is the second pillar. Extensive and efficient infrastructure is critical for ensuring the effective functioning of the economy, as it is an important factor in determining the location of economic activity and the kinds of activities or sectors that can develop within a country. Well-developed infrastructure reduces the effect of distance between regions, integrating the national market and connecting it at low cost to markets in other countries and regions (WEF, 2013, p. 5). According to Global Competitiveness Index, Turkey is the last among five countries, being ranked 49th. The best country among them is Germany. Russia, China, Italy and the USA are also less competitive than Germany. Less-developed infrastructure and the the level of quality and extensiveness of infrastructure in Turkey reduce its competitiveness. Less-developed transport and communications infrastructure also affect Turkey's economy, negatively.

The third pillar is macroeconomic environment. The stability of the macroeconomic environment is important for business and, therefore, is significant for the overall competitiveness of a country (WEF, 2013, p. 6). Global Competitiveness Index shows that macroeconomic environment in Turkey is less-developed. Turkey is ranked as 76th regarding its macroeconomic environment. Russia, China and Germany are above Turkey. Italy and the USA are behind Turkey. As a result of less developed macro economic environment, the Turkish economy cannot grow in a sustainable manner and its impact on competitiveness is negative. It leads to an increased deficit.

Health and primary education are included in the fourth pillar. Healthy workforce is vital to country's competitiveness and productivity. Workers who are ill cannot function to 
their potential and are less productive. Thus, investment in the provision of health services is critical for clear economic as well as moral considerations. In addition, basic education increases the efficiency of each individual worker (WEF, 2013, p. 6). In terms of health and primary education, Turkey's economy is ranked as 59th. Only Russia is behind Turkey. Other countries rank in front of Turkey. One of the most important obstacles in Turkey is weak health and primary education. Weak primary education reduces the efficiency of worker by leading less global competitiveness in Turkey.

The fifth pillar is higher education and training. The current account deficit occurs when the average productivity/skill level is lower than the average income level in a foreign curreny (Ucer, 2011, p. 1). Therefore, qualitative higher education and training are crucial for economies that want to move up the value chain beyond simple production processes and products. In particular, today's globalizing economy requires countries to nurture pools of well-educated workers who are able to perform complex tasks and adapt rapidly to their changing environment and the evolving needs of the production system (WEF, 2013, p. 6). According to Global Competitiveness Index, Turkey is ranked as 65th and is behind Russia, Germany, Italy and the USA. China is ranked as 70th and is behind Turkey. Germany and the USA are the best countries among them. The lower quality of higher education affects the development of the production system and leads to decline in the global competitiveness in Turkey and, thus, to the huge current account deficit.

Goods market efficiency is the sixth pillar. Countries with efficient goods markets are well positioned to produce the right mix of products and services given their particular supply-and-demand conditions, as well as to ensure that these goods can be most effectively traded in the economy. Healthy market competition is important in driving market efficiency and, thus, business productivity, by ensuring that the most efficient firms, producing goods demanded by the market, are those that thrive (WEF, 2013, p. 6). In terms of goods market efficiency, Turkey is ranked as 43rd and comes before Russia, China and Italy. Goods markets in Germany and the USA are better than Turkey. This condition leads to unhealthy market competition as well as lower market efficiency in Turkey.

Table 5: The Global Competitiveness Index 2013-2014: Rank in Basic Requirements (1-6)

\begin{tabular}{|l|c|c|c|c|c|c|}
\hline \multicolumn{1}{|c|}{ Pillars/Countries } & Russia & China & Germany & Italy & USA & Turkey \\
\hline 1-Institutions & 121 & 47 & 15 & 102 & 35 & 56 \\
\hline 2-Infrastructure & 45 & 48 & 3 & 25 & 15 & 49 \\
\hline 3-Macroeconomic Environment & 19 & 10 & 27 & 101 & 117 & 76 \\
\hline 4-Health and Primary Education & 71 & 40 & 21 & 26 & 34 & 59 \\
\hline 5-Higher Education and Training & 47 & 70 & 3 & 42 & 7 & 65 \\
\hline 6-Goods Market Efficiency & 126 & 61 & 21 & 87 & 20 & 43 \\
\hline
\end{tabular}

Source: World Economic Forum, Global Competitiveness Report 2013-2014

Labor market efficiency is the seventh pillar. The efficiency and flexibility of the labor market are critical for ensuring that workers are allocated to their most effective use in the economy and provided with incentives to give their best effort in their jobs. Therefore, labor markets must have the flexibility to shift workers from one economic activity to another rapidly and at low cost, and to allow for wage fluctuations without much social disruption (WEF, 2013, p. 7). According to Global Competitiveness Index, labor market is less effcient in Turkey, being ranked as 130th, and Italy has the worst ranking among them, being ranked 
as 137 th. However, the USA is taking place at the top and is ranked in the 4th place. Russia, China and Germany are ranked as $72 \mathrm{nd}, 34$ th and 41 th, respectively.

The eighth pillar is financial markets developments. The financial and economic crisis has highlighted the central role of a sound and well-functioning financial sector for economic activities. An efficient financial sector allocates the resources saved by nation's citizens, as well as those entering the economy from abroad, to their most productive uses (WEF, 2013, p. 7). In terms of financial developments, Turkey takes place at the middle level and is ranked as 51st. Radical financial sector regulation has continued in 2000s in Turkey. As a result of past crisis experiences, financial system has developed, especially banking sector, but it still needs new regulations, and Turkey is behind the USA and Germany in ranking. Russia and Italy are quite back and China is ranked as 54th.

Technological readiness is the ninth pilllar. In today's globalized world, technology is increasingly essential for firms to compete and prosper (WEF, 2013, p. 8). In terms of technological readiness, Turkey comes behind Germany, Italy and the USA. The rank of Turkey is 58th. However, Russia and China are more behind Turkey, being ranked as 59th and 85th, respectively.

The tenth pillar is market size. The size of the market affects productivity since large markets allow firms to exploit economies of scale. Traditionally, the markets available to firms have been constrained by national borders. In the era of globalization, international markets have become a substitute for domestic markets, especially for small countries. Vast empirical evidence shows that trade openness is positively associated with growth (WEF, 2013 , p. 8). Global Competitiveness Index shows that market size is quite well in the five countries, being ranked as 10th and lower. Turkey is ranked as 16th and is at the back of them. The improvement in the size of the market in Turkey seems moderate. However, Turkey is still behind its main trade partners.

Business sophistication is the eleventh pillar. There is no doubt that sophisticated business practices are conducive to higher efficiency in the production of goods and services. Business sophistication concerns two elements that are intricately linked: the quality of country's overall business networks and the quality of individual firms' operations and strategies. (WEF, 2013, p. 8). In terms of business sophistication, Germany is the best among them and the second best country is the USA. Italy, China and Russia are ranked as 27th, 45 th and 107th, respectively. The quality in business operations and strategies in Turkey is still in development, being ranked as 43rd.

The last pillar is innovation. Innovation can emerge from new technological and non technological knowledge (WEF, 2013, p. 8). Germany and the USA are well-developed in terms of innovation. China and Italy are moderately advanced. Turkey is ranked as 50th and it comes before Russia.

Table 6: The Global Competitveness Index 2013-2014: Rank in Basic Requirements (7-12)

\begin{tabular}{|l|c|c|c|c|c|c|}
\hline \multicolumn{1}{|c|}{ Pillars/Countries } & Russia & China & Germany & Italy & USA & Turkey \\
\hline 7-Labor Market Efficiency & 72 & 34 & 41 & 137 & 4 & 130 \\
\hline 8-Financial Markets Developments & 121 & 54 & 29 & 124 & 10 & 51 \\
\hline 9-Technological Readiness & 59 & 85 & 14 & 37 & 15 & 58 \\
\hline 10-Market Size & 7 & 2 & 5 & 10 & 1 & 16 \\
\hline 11-Business Sophistication & 107 & 45 & 3 & 27 & 6 & 43 \\
\hline 12-Innovation & 78 & 32 & 4 & 38 & 7 & 50 \\
\hline
\end{tabular}

Source: World Economic Forum, Global Competitiveness Report 2013-2014 
As a result, the development in global competitiveness in Turkey is moderate, and it still needs an improvement. In the level of global competitiveness, Turkey is behind its main trade partners: Germany, the USA and China. However, Russia and Italy follow after Turkey. Germany takes place in front of Turkey in all pillars. The USA is also in a better condition than Turkey, excluding macroeconomic environment. China is in a better condition than Turkey in terms of 7 pillars: institutions, infrastructure, macroeconomic environment, health and primary education, labor market efficieincy, market size and innovation. Although Russia and Italy are behind Turkey, they are still well-developed in terms of some pillars. Russia is in a better condition than Turkey in terms of infrastructure, macroeconomic environment, higher education and training, labor market efficiency and market size, while Italy is also better functioning than Turkey in terms of infrastructure, health and primary education, higher education and training, technological readiness, market size, business sophistication and innovation.

\section{Conclusion}

The current account deficit in Turkey exceeded the 7 percent of GDP in 2013 and led to fragility of economy. There are several reasons for the current account deficit: energy dependency, imported raw-material, saving-investment gap and over-valued Turkish lira. The solution will come from removing these reasons. For this, energy imports can be reduced by increasing the share of renewable energy sources used in the total production of electric power. Research and development efforts on alternative energy sources should be much more supported in order to reduce dependence on foreign-sourced energy. Boosting productivity also requires pushing ahead with product market reforms. Greater competition in energy, metal, chemical, automotive and machinery would benefit consumers and economy-wide competitiveness, and help reduce the external deficit. Turkey can also increase its domestic savings. All parts of the financial sector and insurance sector can be restructured to encourage more savings. Development of investment funds and personal pension systems can be supported by incentives. In addition, the depreciation in the real exchange rate may help reduce the foreign trade deficit and, therefore, the current account deficit, as well. The exchange rate needs to stay on a sustainable path (Terzi, 2014, p. 293).

The most important reason for the current account deficit in Turkey is the low global competitiveness level. Global competitiveness takes place in the center of reasons of the current account deficit in Turkey. Therefore, it is important to raise the level of global competiveness, thus, it will help to reduce the persistent deficit in Turkey. Global competitiveness is also essential to rebalance the economy from domestic to external demand, as well as to sustain employment, income and domestic savings growth. Competitiveness gains particular improvement in employment opportunities of the low-skilled, and hence it directly helps to reduce poverty and foster social cohesion.

As the most part of the current account deficit comes from the trade deficit, it is crucial to decrease the imports of Turkey. The countries which play an important role on the imports of Turkey are Russia, China, Germany, Italy and the USA. They were the top 5 countries in imports in Turkey in 2013, as well. To compare Turkey and its main trade partners in terms of global competitiveness will help to understand the deficiencies of economy. According to Global Competitive Index, they are ranked as 64th, 29th, 4th, 49th and 5th in average, respectively (Russia, China, Germany, Italy and the USA). Turkey is placed as 44th 
in rankings. Turkey is behind the USA, Germany and China, but it is ahead of Russia and Italy in rankings.

What are the global competitive differences between Turkey and its main trade partners? In terms of 12 pillars of Global Competitiveness Index, Germany is in a better condition than Turkey in all pillars, the USA is well-developed than Turkey in 11 pillars, except macroeconomic environment. As a result, Germany and the USA are the strongest competitors for Turkey in trade. China is more ahead than Turkey in 7 pillars. Russia and Italy are also better-functioning than Turkey at least for 4 pillars, as explained above.

Turkey should take advantage for 12 pillars (institutions, infrastructure, macroeconomic environment, health and primary education, higher education and training, goods market efficieny, labour market efficiency, financial market developments, technological readiness, market size, business sophistication, innovation) of global competitiveness to decrease the current account deficit. Turkey should also carry its competitive level higher. A higher level of competitiveness in Turkey will help to fight against deficit.

Especially, Turkey is at the worst condition among its main trade partners in terms of infrastructure and market size in the global level. These two pillars are the priority areas for the development in Turkey. Extensive and efficient infrastructure is critical for ensuring the effective functioning of the economy and well-developed infrastructure will reduce the effect of distance between regions. In addition, a well-developed transport and communications infrastructure network should also be prerequisite for the comparative advantage. Market size is another important field in Turkey. Because the size of the market affects productivity and allows firms to exploit economies of scale, Turkey should provide more trade and financial openness than before.

Primary and higher education are other priority fields in Turkey. Qualitative higher education and training are crucial for economies that want to move up the value chain beyond simple production processes and products. In particular, today's globalizing economy requires well-educated workers to achieve more complex tasks. This also will help to provide the efficiency and flexibility of the labor market by increasing production. Innovation is another neccessity in Turkey. Higher technological knowledge will bring the quality and diversity of goods. This process automatically will help to create value-added products and thus increase trade in Turkey.

To conclude, Turkey is the largest deficit economy. This permanent deficit is putting on a pressure on economic growth. Therefore, further policy action is needed to contain the global competitiveness. Additional policy options can be considered in all pillars in both short term and long term. An increase in global competitiveness will make Turkey's current account stronger, and it will also make it more stable to external economic fluctuation.

\section{References}

Abdullah, M.L. (2014). The Imperatives for Enchanging Global Competitiveness. Asian Productivity Organization. Retrieved May 31, 2014 from http://www.apo-tokyo.org/productivity/078_prod.htm, p. 1-3.

Appleyard, D., Field, A., and Cobb, S. (2010). International Economics (7th ed.). Mc-Graw-Hill Irwin. Carbaugh, R. J. (2006). International Economics (10th ed.). Ohio: South-Western College Publishing. CBRT. (2013). Balance of Payments Report 2013-III.

CBRT. (2014). Central Bank of the Republic of Turkey. Retrieved May 20, 2014 from http://evds.tcmb. gov.tr/cbt.html. 
Ferguson, R. (2005). US Current Account Deficit: Causes and Consequences. W. Chapel Hill, North Carolina, April 20. Retrieved May 10, 2014 from http://www.federalreserve.gov/boarddocs/Speeches/ 2005/20050420/default.htm.

OE CD. (2012). Economic Surveys Turkey, Overview, July.

TDM. (2014). Turkey Data Monitor. Retrieved May 20, 2014 from http://www.turkeydatamonitor.com/ contact_eng.html.

Terzi, N. (2014). Current Account Deficit in Turkey and its Possible Solutions. 3rd International Scientific Conference "Practice and Research in Private and Public Sector", Vilnius 2014, p. 286-294.

TSI. (2014). Turkish Statistical Institutes Data. Retrieved May 24, 2014 from http://www.turkstat.gov. tr/ UstMenu.do?metod=temelist.

World Economic Forum. The Global Competitiveness Reports, 2004-2013.

WB. (2014). Turkey Regular Economic Brief. 1: 1-2.

TME. (2014). Republic of Turkey Ministry of Economy. Retrieved May 24, 2014 from www.economy. gov.tr.

Ucer, M. (2011). Cari Açık Ne Anlama Gelir? Radikal. Retrieved July 9, 2011 from http://www.radikal. com.tr/yorum/cari_acik_ne_anlama_gelir-1055656.

YASED-Int. Investor Association (2011). Current Account Deficit in Turkey: Macro and Micro Reasons and Suggested Solutions.International Investors Association. Retrieved May 30, 2014, from http:// www.yased.org.tr/webportal/English/insight_yased/Documents/YASED_Current_Account_ Deficit_Report_2012.pdf.

\title{
TURKIJOS EINAMOSIOS SĄSKAITOS DEFICITAS IR KONKURENCINGUMAS PASAULYJE
}

\author{
Nuray TERZI \\ Marmara universitetas, Turkija
}

Santrauka. Einamosios sąskaitos deficitas buvo vienas pagrindinių politikos klausimų pastaraisiais metais Turkijoje, nes Turkijos einamosios sąskaitos deficitas viršijo priimtinos rizikos lygị. Politikai baiminasi, kad augantis einamosios sąskaitos deficitas gali dar labiau pakenkti Turkijai ateityje ir padaryti jos ekonomiką mažiau atsparią išoriniams ekonomikos svyravimams. Didžiausią įtaką einamosios sąskaitos deficitui Turkijoje turèjo padidejęs prekybos deficitas, todèl pagrindinis dèmesys skiriamas Turkijos importui iš kai kurių konkrečių šalių. Turkijos ir jos prekybos partnerių konkurencingumo palyginimas pasauliniu mastu suteiks j̇žvalgų, kaip mažinti deficitą, taip pat ir einamosios sąskaitos deficitą. Dèl šios priežasties šiame straipsnyje siekiama palyginti Turkijos ir jos pagrindinių prekybos partnerių konkurencingumo lygị pasauliniu mastu.

Reikšminiai žodžiai: einamosios sąskaitos deficitas, prekybos deficitas, konkurencingumas pasaulyje. 